in 1981 were estimated to be taking $\beta$ blockers, ${ }^{11}$ but nearly all of them would have to have survived because of $\beta$ blockade for this to account solely for the increased survival rates; this is unlikely given the modest effect on survival of $\beta$ blockers taken after infarction. ${ }^{12}$ The hazards of continued smoking after myocardial infarction became widely recognised in the early $1970 \mathrm{~s},{ }^{13}$ and as the need to stop smoking now receives much more emphasis in hospital than it did in the 1960s we suspect that this may be the most important factor contributing to improved survival.

Our results suggest that an improvement in long term survival after myocardial infarction contributed to the decline in mortality from coronary heart disease in New Zealand, but there is as yet no evidence that it is continuing to do so. Further reductions in mortality from coronary heart disease are likely only if emphasis is placed on primary prevention.

We thank Dr P W T Brandt for his advice on interpreting the chest $x$ ray films and the Medical Research Council of New Zealand and the National Heart Foundation for their support of the 1981-2 study. AWS was funded by the Medical Research Council of New Zealand.
Beaglehole R, Bonita R, Jackson R, Stewart A. Cardiovascular mortality in New Zealand and Australia 1968-1983: how can the diverging trends be explained? NZ Med f 1986:99:1-3.

2 Beaglehole R, Bonita R, Jackson R, Stewart A, Sharpe N, Fraser GE. Trends in coronary heart disease event rates in New Zealand 1974-81. Am $\mathcal{J}$ Epidemiol 1984;184:225-35

3 Stewart AW, Beaglehole R, Fraser GE, Sharpe DN. Trends in survival after myocardial infarction in New Zealand 1974-81. Lancet 1984;ii:444-6.

4 Stewart AW, Beaglehole R, Fraser GE, Sharpe DN. Has the long term prognosis following myocardial infarction improved? NZ Med $\mathcal{F}$ 1986;99. $403-5$

5 Norris RM, Brandt PWT, Caughey DE, Lee AJ, Scott PJ. A new coronary prognostic index. Lancet 1969;i:274-8.

6 Norris RM, Caughey DE, Deeming LW, Mercer CJ, Scott PJ. Coronary prognostic index for predicting survival

עe 1969. (Working party report, part 2.)

8 SAS Institute. SUGI supplemental library user's guide, version 5 th ed. Cary, North Carolina: SAS Institute, 1986 .

9 Aberg A, Bergstrand R, Johansson S, et al. Declining trend in mortality after myocardial infarction. Br Heart $\mathcal{f}$ 1984;51:346-51.

10 Gomez-Marin O, Folsom AR, Kottke TE, et al. Improvement in long term survival among patients hospitalized with acute myocardial infarction, 1970 to 1980. N Engl f Med 1987;316:1353-9.

11 Beaglehole R. Medical management and the decline in mortality from coronary heart disease. Br Med J 1986;292:33-5.

12 Barber NS, Lewis JA. Confidence in results of beta-blocker post infarction trends. BrMed $\mathcal{7}$ 1982;285:1749-50

13 Wilhelmsson C, Vedin JA, Elmfeldt D, Tibblin G, Wilhelmsen L. Smoking and myocardial infarction. Lancet $1975 ;$; $415-20$.

(Accepted 20 May 1988)

\title{
Postmenopausal oestrogen treatment and stroke: a prospective study
}

\author{
Annlia Paganini-Hill, Ronald K Ross, Brian E Henderson
}

\section{Abstract}

Study objective-To determine whether postmenopausal oestrogen use affects the risk of dying from stroke.

Design-Postal questionnaire survey to elicit details of oestrogen replacement therapy and potential risk modifiers.

Setting-Californian retirement community.

Participants-All 22781 residents of community (white, affluent, well educated) contacted by mail and phone; $13986(61 \%$, median age 73$)$ responded, including $\mathbf{8 8 8 2}$ women. These formed cohort for mortality follow up, using health department death certification. Only 13 lost to follow up, apparently not deceased, but 34 excluded because no information on oestrogen use.

Interventions-None.

End point-Mortality rate from stroke compared in women who did and did not receive oestrogen replacement treatment.

Measurements and main results-Age adjusted mortality rates were computed using internal standard and four age groups. By January 1987 there had been 1019 deaths in the cohort. Twenty out of 4962 women who used oestrogen replacement treatment died from stroke compared with 43 out of 3845 women who did not use oestrogen replacement treatment: relative risk $0.53,95 \%$ confidence interval 0.31 to 0.91 . Protection was found in all age groups except the youngest and was unaffected by adjustment for possible confounding factors (hypertension, smoking, alcohol, body mass index, exercise)

Conclusions-Oestrogen replacement treatment protects against death due to stroke.

\section{Introduction}

Although mortality rates are declining, stroke continues to be the third leading cause of death in the
United States after heart disease and cancer ${ }^{1}$ as well as a major contributor to disability. Since stroke is often fatal and the impact of treatment on prognosis is limited, control of the disease must be through primary prevention.

Recent cohort and case-control studies have suggested that the use of oestrogen replacement treatment by postmenopausal women protects against death and admission to hospital due to cardiovascular disease. ${ }^{2 \cdot 15}$ As some of the major risk factors for heart disease are also risk factors for stroke, we examined the association of postmenopausal hormone use and stroke in a prospective study conducted in a retirement community in southern California. The study design provided the opportunity of obtaining details on potential risk modifiers, such as prior heart disease, hypertension, cigarette smoking, alcohol intake, exercise, and weight, as well as on the dose and duration of use of oestrogens.

\section{Methods}

In June 1981 a health questionnaire was mailed to all residents of Leisure World, Laguna Hills, a retirement community near Los Angeles, California. New residents who moved into the community after this date were mailed the questionnaire in June 1982, June 1983, and October 1985. Residents of this community are almost entirely white, moderately affluent, and well educated. The residents' median age was 73 at the time of the initial mailing, and about two thirds were women. After three mailings and follow up telephone contact $13986(61 \%)$ of the 22781 residents returned questionnaires; 8882 of these respondents were women

The health questionnaire requested information on certain medical diagnoses including stroke, angina, myocardial infarction, and hypertension; height and weight; consumption of cigarettes and alcohol; and, for women, menstrual and reproductive events, including gynaecological operations. Detailed information was collected on the use of oestrogens during the meno- 
pause, including routes of administration (injectable, oral, vaginal) and the duration of treatment. For the most commonly used oral oestrogen, Premarin (conjugated oestrogens), the rolour of the pills was used to help identify the dosage taken.

The cohort is being followed for deaths using the death certificate records of the local county health department. Death certificates are also obtained for others known to have died because of information from the community business office, from the obituary columns of the local newspaper, and from relatives and friends. We have also conducted a biennial remailing to the cohort. To date only 13 cohort members have been lost to follow up; a search of the national death index did not show that they had died.

Age adjusted mortality rates were computed by direct standardisation using an internal standardthat is, the person years distribution of the total cohort under study ${ }^{16}$ - and four age groups. Relative risks and $p$ values were obtained using a regression method that assumed that the occurrence of death could be regarded as a Poison process with a constant hazard rate for a given person. ${ }^{17}$ The GLIM statistical software package program was used to make these calculations. ${ }^{i 8}$ All reported $p$ values are two-sided.

\section{Results}

By 1 January 1987, 1019 deaths had occurred among the 8841 women who returned the initial questionnaire before that date (41 women returned the questionnaire in 1987). Thirty four women provided no information on oestrogen use and were excluded from further analyses related to this variable. There were 442 deaths among the 4962 women who had used oestrogen replacement treatment and 563 among the 3845 women who had not, vielding an age-adjusted relative risk (RR) of $0.80(95 \%$ confidence interval 0.70 to $0.91)$. The age specific and age adjusted death rates for stroke by history of oestrogen use are given in table I.

TABLE I-Mortality from stroke per 1000 person-years (and numbers of deaths) from stroke by age and use of oestrogen replacement treatment

\begin{tabular}{lccc}
\hline & & \multicolumn{2}{c}{ Oestrogen replacement } \\
\cline { 3 - 4 } & No of & & \\
Age & $\begin{array}{c}\text { Nollow up } \\
\text { years }\end{array}$ & Never used & Ever used \\
\hline$<75$ & 16872 & $0 \cdot 4(2)$ & $0 \cdot 4(4)$ \\
$75-79$ & 10806 & $1 \cdot 5(7)$ & $0 \cdot 3(2)$ \\
$80-84$ & 8423 & $3 \cdot 2(14)$ & $1 \cdot 0(4)$ \\
$\geqslant 85$ & 4682 & $6 \cdot 8(20)$ & $5 \cdot 7(10)$ \\
No of follow up years & & 17624 & 23159 \\
Age adjusted & & $2 \cdot 0(43)$ & $1 \cdot 1(20)$ \\
Relative risk (95\% CI & & $1 \cdot 00$ & $0.53(0 \cdot 31$ to 0.91$)$ \\
Two sided p & & & 0.02 \\
\hline
\end{tabular}

There were 20 deaths due to stroke among the women who had used oestrogen replacement treatment and 43 among those who had never used oestrogens, yielding an age adjusted relative risk of $0.53(95 \%$ confidence interval 0.31 to 0.91 ). All age groups except the youngest showed a substantial reduction in risk.

A history of stroke $(\mathrm{RR}=5.2, \mathrm{p}<0.0001)$ and of angina or acute myocardial infarction $(R R=2 \cdot 0)$, $p=0.02$ ) were each significant risk factors for death from stroke. Women with a history of hypertension had a non-significantly increased risk of death from stroke $(R R=1 \cdot 5, p=0 \cdot 12)$. Current smokers had an increased mortality from stroke compared with those who had never smoked, but this increased risk was not statistically significant. There was a significant trend of decreasing risk with increasing physical exercise $(p=0.001)$. In those who had never used oestrogen replacement treatment, the rate of deaths from stroke decreased with increasing body mass index, with increasing age at menopause, and with decreasing alcohol consumption.

Users of oestrogens had a lower mortality from stroke than non-users in the presence or absence of each and all of these potential risk modifiers or confounding variables (table II). Adjustment for each of these factors separately and simultaneously did not appreciably change the relative risk of mortality from stroke observed for oestrogen users compared with non-users.

TABLE II-Age adjusted mortality for stroke per 1000 person-years (and numbers of deaths) by use of oestrogen and other risk factors

\begin{tabular}{|c|c|c|c|c|}
\hline \multirow[b]{2}{*}{ ()ther risk factor } & \multirow{2}{*}{$\begin{array}{l}\text { No of } \\
\text { follow up } \\
\text { yearst }\end{array}$} & \multicolumn{2}{|c|}{ Oestrogen replacement } & \multirow{2}{*}{$\begin{array}{c}\text { Relative } \\
\text { risk } \neq\end{array}$} \\
\hline & & Never used $t$ & Ever used $\dagger$ & \\
\hline \multicolumn{5}{|l|}{ Previous stroke } \\
\hline No & 39382 & $1 \cdot 6(33)$ & $0.9(16)$ & \multirow{2}{*}{0.50} \\
\hline Yes & 1365 & $10 \cdot 6(10)$ & $3 \cdot 6(3)$ & \\
\hline \multicolumn{5}{|c|}{$\begin{array}{l}\text { Previous myocardial } \\
\text { infarction/angina }\end{array}$} \\
\hline No & 35617 & $1.7(31)$ & $1 \cdot 0(15)$ & \multirow{2}{*}{0.51} \\
\hline Yes & 5070 & $3.8(12)$ & $1.6(5)$ & \\
\hline \multicolumn{5}{|c|}{$\begin{array}{l}\text { Previous high blood } \\
\text { pressure }\end{array}$} \\
\hline No & 24371 & $1 \cdot 8(23)$ & $0 \cdot 7(7)$ & \multirow{2}{*}{0.53} \\
\hline Yes & 16392 & $2 \cdot 2(20)$ & $1.5(13)$ & \\
\hline \multicolumn{5}{|l|}{ Smoking } \\
\hline Never & 22552 & $1 \cdot 4(24)$ & $1.0(12)$ & \multirow{3}{*}{0.52} \\
\hline Past & 12995 & $3.0(14)$ & $1 \cdot 4(7)$ & \\
\hline Current & 5111 & $2.515)$ & $0 \cdot 2(1$ & \\
\hline \multicolumn{5}{|c|}{ Alcohol (drinks day) } \\
\hline None & 10948 & $1.7(13)$ & $1 \cdot 4(7)$ & \multirow{3}{*}{0.53} \\
\hline$\leqslant 1$ & 19635 & $1.8(18)$ & $1 \cdot 2(11)$ & \\
\hline$\geqslant 2$ & 10153 & $2 \cdot 9(12)$ & $0.4(2)$ & \\
\hline \multicolumn{5}{|l|}{ Body mass index ${ }^{\star}$} \\
\hline$\leqslant 30^{\circ}$ & 15569 & $2 \cdot 5(24)$ & $0 \cdot 9(7)$ & \multirow{3}{*}{0.55} \\
\hline $31-34$ & 13869 & $1.9(13)$ & $1.6(10)$ & \\
\hline$\geqslant 35$ & 11144 & $0.8(4)$ & $0.7(3)$ & \\
\hline \multicolumn{5}{|l|}{ Exercise (h/day) } \\
\hline$<0.5$ & 12944 & $2 \cdot 9(26)$ & $1 \cdot 6(12)$ & \multirow{3}{*}{$0 \cdot 50$} \\
\hline$<1 \cdot 0$ & 11336 & $1.6(9)$ & $0.6(4)$ & \\
\hline$\geqslant 1$ & 16124 & $1 \cdot 2(8)$ & $0 \cdot 7(3)$ & \\
\hline \multicolumn{5}{|c|}{ Age at last menstrual } \\
\hline$<45$ & 10771 & $2 \cdot 2(12)$ & $1 \cdot 6(8)$ & \multirow{3}{*}{0.55} \\
\hline $45-54$ & 24569 & $1.9(24)$ & $0 \cdot 9(9)$ & \\
\hline$\geqslant 55$ & 34554 & $1.6(3)$ & $1.4(3)$ & \\
\hline
\end{tabular}

${ }^{\star} 1000 \times\left(\right.$ weight $(\mathrm{lb}) /\left(\right.$ height $\left.(\text { in })^{2}\right)$

tFollow up years do not always total 40783 nor number of deaths 63 owing to women with missing values.

$\ddagger$ Relative risk for oestrogen users compared to non-users after adjusting for the other risk factor.

The duration of treatment was evaluated as the total number of years of all types of oestrogen replacement treatment, regardless of route of administration. The dose was available only for women taking oral conjugated oestrogens. The reported dose was that taken for the longest period of time. Altogether 4433 (89\%) oestrogen users had used oral oestrogen for.at least part of the time, and $3049(61 \%)$ had used only this form of oestrogen replacement treatment. In table III mortality rates from stroke are given by duration and dose of oestrogen. Women who had ised primarily a high dose $(\geqslant 1 \cdot 25 \mathrm{mg}$ conjugated equine oestrogen) had a relative risk slightly lower than that of women who had used a lower dose, but the number of deaths in each category was small and there was considerable overlap in the $95 \%$ confidence intervals of these two

TABLE III-Age adjusted mortality from stroke per 1000 person-years and numbers of deaths by duration and dose of oestrogen replacement treatment

\begin{tabular}{lccccc}
\hline $\begin{array}{c}\text { Oestrogen } \\
\text { replacement }\end{array}$ & $\begin{array}{c}\text { No of } \\
\text { follow up } \\
\text { years }\end{array}$ & Rate & $\begin{array}{c}\text { No of } \\
\text { deaths }\end{array}$ & $\begin{array}{c}\text { Relative } \\
\text { risk }\end{array}$ & $95 \% \mathrm{CI}$ \\
\hline $\begin{array}{l}\text { Never used } \\
\text { Duration } \\
\quad 17 \text { years }\end{array}$ & 17624 & 2.0 & 43 & 1.00 & \\
$\begin{array}{c}>8 \text { years } \\
\text { Dose } \\
\quad 10.625 \mathrm{mg}\end{array}$ & 11168 & 1.1 & 11 & 0.55 & 0.28 to 1.08 \\
$\quad \geqslant 1.25 \mathrm{mg}$ & 6798 & 1.2 & 8 & 0.50 & 0.23 to 1.08 \\
\hline
\end{tabular}

*Follow up years do not always total 40783 nor number of deaths 63 owing to women with missing values. 
risk estimates. When duration of use was evaluated by dividing the group into two according to whether the women had taken oestrogen treatment for more or less than the median ( 8 years) there was no large difference in risk. Protection from death from stroke was greatest among more recent users $(p=0 \cdot 03$, test for trend). Recent users (those who were using oestrogen at the time of the initial questionnaires) had a relative risk of 0.21 and past users a risk of 0.67 relative to those who had never had treatment, but the former risk estimate was based on just one death from stroke.

\section{Discussion}

These results suggest that postmenopausal oestrogen replacement treatment protects against death due to stroke. Women who had used oestrogen replacement treatment had a risk of mortality from stroke of 0.53 relative to women who had never taken menopausal oestrogens. The reduction in risk of death from stroke in oestrogen users was comparable with that previously observed in this community for deaths due to acute myocardial infarction." This protective effect of oestrogen was not explained by differences between users and non-users in a history of known risk factors for stroke, including previous stroke, angina or myocardial infarction, hypertension, obesity, alcohol consumption, and cigarette smoking.

The only previous study describing the relation between postmenopausal oestrogen treatment and the risk of stroke was done by Pfeffer and Van den Noort, ${ }^{14}$ who conducted a case-control study covering the period 1964-73 among residents of this same retirement community. Using death certificates and hospital discharge summaries to identify their cases and medical centre pharmacy records to estimate oestrogen exposure, they found no relation between oestrogen use and stroke. By this method of identifying oestrogen exposure, however, only $27 \%$ of study subjects had used oestrogen and only $45 \%$ of these had used oestrogen for more than 12 months. We have previously expressed concerns about the completeness of these pharmacy records and the potential bias introduced by using records from the convenient pharmacy in the medical centre of the community as the sole source of data on oestrogen use..$^{20}$

As with cardiovascular disease, one possible mechanism for the protection from stroke afforded by oestrogen use is the effect of oestrogens on lipid secretion and metabolism. Users of oestrogen replacement treatment have reduced low density and increased high density lipoprotein cholesterol concentrations. " $"$ Although several studies have found no association between lipid concentrations and stroke, ${ }^{12}$ or a negative association, ${ }^{20.2 x}$, increased serum cholesterol concentrations have been reported as a risk factor in the Framingham study. ${ }^{29}$ None the less, alternative mechanisms to explain this considerable reduction in the risk of fatal stroke among oestrogen users should be evaluated. For example, oestrogens may cause vasodilatation through their stimulatory effects on prostacyclins. ${ }^{30}$

The major risk factors for stroke have recently been reviewed. ${ }^{31}$ The results of virtually all the large prospective studies suggest that raised blood pressure is the dominant risk factor. ${ }^{23: 2323}$ Hypertension was a risk factor in our study population as well. There is a common belief that oestrogen treatment predisposes women to an increase in blood pressure and that hypertension may be a contraindication to oestrogen treatment. ${ }^{36}$ Importantly, our study showed a reduction in mortality from stroke with oestrogen use in both women with a history of hypertension and those without. Although a small percentage of oestrogen users may experience an idiosyncratic increase in blood pressure, recent studies have shown that most women taking oestrogen replacement treatment actually experience a decline in blood pressure. ${ }^{37 \text { ix }}$ We are uncertain whether or not this effect of oestrogen played any part in the reduction of mortality from stroke experienced by oestrogen users in our cohort.

Previous cardiac disease has been identified as a risk factor for stroke by most $3: 34$ i4: but not all ${ }^{25}$ studies. Our data support the former group of studies.

Results have been less conclusive about the roles of cigarette smoking, alcohol consumption, and obesity. Smoking has been shown to be a risk factor for stroke in men in some studies ${ }^{32+1+2}$ but not in others ${ }^{22^{25}+1+3}$ and not in women. ${ }^{+0+1}$ Our data suggest an increased risk of death from stroke in past women smokers and those currently smoking relative to those who had never smoked, but this increase was not statistically significant.

Although associated with both hypertension and cigarette smoking, alcohol intake has been found to be independently associated with stroke..$^{26} 27$ Recent reports have implicated habitual daily drinking and have shown an excess of deaths from stroke with frequent intoxication or binge drinking. ${ }^{4+4}$ Our data suggest some increased risk in the most extreme category of alcohol intake, but only among nonoestrogen users.

Obesity, although related to hypertension, has not been consistently found to be an independent risk factor for stroke. Our data in elderly women who were not taking oestrogen replacement treatment actually suggest a reduction in risk with increased body mass index. If oestrogens do reduce the risk of death from stroke mortality our observation should come as no surprise. In postmenopausal women the primary source of circulating oestrogens is through conversion of adrenal derived androstenedione to oestrone in adipose tissue. ${ }^{\text {th }}$ In addition sex hormone binding globulin concentrations are lower in obese women, further increasing the amount of bioavailable oestrogen. ${ }^{4}$

Although a high level of physical activity protects against death from coronary heart disease mortality, ${ }^{4 \times 53}$ a strong relation between the risk of stroke and vocational physical activity has not emerged. Pfaffenbarger and Williams ${ }^{32}$ and Herman et $a l$, ${ }^{\text {t1 }}$ however, found that physical activity reduced mortality from stroke. The strong inverse relation between recreational physical activity and death from stroke observed in our population needs to be carefully evaluated in other population based studies.

Though our data on both oestrogen use and other variables are self reported, we have evidence that these data are both reliable and valid. A previous comparison in this community of health related information obtained by interview with that obtained from medical records indicated good agreement (over 90\%) even for a disease such as hypertension for which diagnostic criteria vary. ${ }^{21}$ Previous studies of oestrogen use in this community have found an extremely good correlation in relative risks for various chronic diseases whether oestrogen use was ascertained by interviews, from medical records, or from pharmacy records..$^{546}$

We thank our research staff-Mary Arthur, Ann Chao, Beverly Ducey-for their invaluable help and are indebted to the residents of Leisure World, Laguna Hills, whose cooperation made this work possible.

This study was supported by grants CA32197, CA00652, and CA17054 from the National Cancer Institute, National Institutes of Health, Bethesda, MD.

1 US Department of Health and Human Services. Prevention ' 82 . Washington,
DC: US Government Printing Office, 1982. DHSS (PHS) Publication No DC: US Government Printing Office, 1982. DHSS (PHS) Publication No
82.50157. 
2 Burch JC, Byrd BF, Vaughn WK. The effects of long-term estrogen on hysterectomized women. Am J Obstet Gynecol 1974;118:778-82.

3 Rosenberg L, Armstrong B, Jick $\mathrm{H}$. Myocardial infarction and estrogen therapy in postmenopausal women. N Engl f Med 1976;294:1256-9.

4 Pfeffer RI, Whipple GH, Kurosaki TT, Chapman JM. Coronary risk and estrogen use in postmenopausal women. Am f Epidemiol 1978;107:479-87.

5 Jick H, Dinan B, Rothman KJ. Noncontraceptive estrogens and nonfatal myocardial infarction. FAMA 1978;239:1407-8.

6 Gordon T, Kannel WB, Hiortland MC, McNamara MP. Menopause and coronary heart disease: The Framingham Study. Ann Intern Med 1978;89 $157-61$.

7 Hammond CB, Jelovsek FR, Lee KL, Creasman WT, Parker RT. Effects of long-term estrogen replacement therapy. I. Metabolic effects. Am $\mathcal{f}$ Obste Gynecol 1979:133:525-36

8 Rosenberg I, Slone D, Shapiro S, Kaufman D, Stolley PD, Miettinen OS Noncontraceptive estrogens and myocardial infarction in young women. JAMA 1980;244:339-42

9 Ross RK, Paganini-Hill A, Mack TM, Arthur M, Henderson BE. Menopausa oestrogen therapy and protection from death from ischaemic heart disease. Lancet $1981 ; i: 858-60$.

10 Bain C, Willett W, Hennekens CH, Rosner B, Belanger C, Speizer FE. Use of postmenopausal hormones and risk of myocardial infarction. Circulation $1981 ; 64: 42-6$

11 Adam S, Williams V, Vessey MP. Cardiovascular disease and hormone replacement treatment: A pilot case-control study. $B r \operatorname{Med} \mathcal{J} 1981 ; 282$ : $1277-8$

12 Bush TL, Cowan LD, Barrett-Connor E, Criqui MH, Karon JM. Estrogen use and all-cause mortality. $\mathcal{F} A M A$ 1983;249:903-6.

13 Szklo M, Tonascia J, Gordis L, Bloom I. Estrogen use and myocardia infarction risk: a case-control study. Prev Med 1984;13:510-6.

14 Stampfer MJ, Willett WC, Colditz GA, Rosner B, Speizer FE, Henneken $\mathrm{CH}$. A prospective study of postmenopausal estrogen therapy and coronary heart disease. $N$ Engl I Med 1985;313:1044-9.

15 Petitti DB, Perlman JA, Sidney S. Postmenopausal estrogen use and heart disease. N Engl f Med 1986;315:131-2.

16 Lilienfeld AB, Lilienfeld DE. Foundations of epidemiology. New York: Oxford University Press, 1980.

17 Breslow NE, Lubin JH, Marek P, Langholz B. Multiplicative models an cohort analysis. Fournal of the American Statistical Society 1984;78:1-12.

18 Royal Statistical Society. Generalized linear interactive modality, the GLIM system. Release 3. Oxford: Numerical Algorithms Group, 1978.

19 Pfeffer RI, Van den Noort S. Estrogen use and stroke risk in postmenopausal women. Am J Epidemiol 1976;103:445-56.

20 Paganini-Hill A, Ross RK. Reliability of recall of drug usage and other health related information. Am f Epidemiol 1982;116:114-22.

21 Wahl P, Walden C, Knopp R. Effect of estrogen/progestin potency on lipid lipoprotein cholesterol. $N$ Engl f Med 1983;308:862-7.

22 Wallentin L, Larsson-Cohn U. Metabolic and hormonal effects of postmenopausal oestrogen replacement treatment. II. Plasma lipids. Acta Endocrinol (Copenh) 1977;86:597-607.

23 Heyman A, Karp HR, Heyden S, et al. Cerebrovascular disease in the biracia population of Evans County, Georgia. Arch Intern Med 1971;128:949-55.

24 Tanaka H, Hayashi M, Date C, et al. Epidemiologic studies of stroke in Shibata, a Japanese provincial city: preliminary report on risk factors for cerebral infarction. Stroke $1985 ; 16: 773-80$

25 Welin L, Svardsudd K, Wilhelmsen L, Larsson B, Tibblin G. Analysis of risk factors for stroke in a cohort of men born in 1913. N Engl f Med 1987;317:521-6.

26 Kagan A, Popper JS, Rhoads GG. Factors related to stroke incidence in Hawail Japanese men: the Honolulu Heart Study. Stroke 1980;11:14-21.

27 Tanaka $\mathrm{H}$, Ueda $\mathrm{Y}$, Hayashi $M$, et al. Risk factors for cerebral hemorrhage and cerebral infarction in a Japanese rural community. Stroke 1982;13:62-73.

28 Kagan A, Popper J, Rhoads GG, et al. Epidemiologic studies of coronary hear disease and stroke in Japanese men living in Japan, Hawaii and California: prevalence of stroke. In: Schunberg P, ed. Cerebrovascular diseases. New York: Raven Press, 1976:267.

29 Kannel WB, Wolf PA, Verter J, McNamara PM. Epidemiologic assessment of the role of blood pressure in stroke: the Framingham study. FAMA $1970 ; 214: 301-10$
30 Makila U-M, Wahlberg L, Viinikka L, Ylikorkala O. Regulation of prostacyclin and thromboxane production by human umbilical vessels, the effect of estradiol and progesterone in a superfusion model. Prostaglandin Leukotrienes Med 1982;85:115.

31 Dyken ML, Wolf PA, Barnett HJM, et al. Risk factors in stroke: a statement for physicians by the subcommittee on risk factors and stroke of the Stroke Council. Stroke 1984;15:1105-11.

32 Paffenbarger RS Jr, Williams JL. Chronic disease in former college students. V. Early precursors of fatal stroke. Am f Pub Health 1967;57:1290-9.

33 Kannel WB, Wolf P, Dawber TR. Hypertension and cardiac impairments increase stroke risk. Geriatrics 1978;33:71-83.

34 Paffenbarger RS Jr, Gima AS, Laughlin ME, Black RA. Characteristics of longshoremen related to fatal coronary heart disease and stroke. Am f Public Health 1971:61:1362-70.

35 Paffenbarger RS Jr, Laughlin ME, Gina AS. Work activity of longshoremen as related to death from coronary heart disease and stroke. $N$ Engl $\mathrm{Med}$ 1970;2:1109.

36 Lobo RA. Estrogen replacement therapy and hypertension. Postgraduate Medicine 198714 Sept:48-54. (Special Report.)

37 Wren BG, Brown LB, Routledge DA. Differential clinical response to oestrogens after menopause. Med f A ust 1982;2:329-32.

38 Lind T, Cameron EC, Hunter WM, et al. A prospective, controlled trial of six forms of hormone replacement therapy given to postmenopausal women. Br 7 Obstet Gynecol 1979;86:(suppl 3): 1-29.

39 Kannel WB, Wolf PA, Verter J. Manifestations of coronary disease predisposing to stroke: the Framingham study. JAMA 1983;250:2942-6.

40 Herman B, Leyten ACM, van Luijk JH, Frenken CWGM, Op de Coul AAW, Schulte BPM. An evaluation of risk factors for stroke in a Dutch communitv. Stroke 1982;13:334-9.

41 Salonen JT, Puska P, Tuomilehto J, Homan K. Relation of blood pressure, serum lipids, and smoking to the risk of cerebral stroke: a longitudinal study in eastern Finland. Stroke 1982;13:327-33.

42 Abbott RD, Yin Y, Reed DM, Yano K. Risk of stroke in male cigarette smokers. New Engl f Med 1986;315:717-20.

43 Kagan A, Popper JS, Rhoads GG, Yano K. Dietary and other risk factors for stroke in Hawaiian Japanese men. Stroke 1985;16:390-6.

44 Taylor JR. Alcohol and stroke. N Engl f Med 1982;306:1111.

45 Gill JS, Beevers DG, Tsmentzis SA. Strokes and alcohol. Lancet ii: 1142-3.

46 MacDonald PC, Edman CD, Hemsell DL, Porter JC, Siiteri PK. Effect of obesity on conversion of plasma androstenedione to estrone in postmenopausal women with and without endometrial cancer. Am $\mathcal{F}$ Obstet Gynecol 1978;130:448-55.

47 Anderson DC. Sex-hormone-binding globulin. Clin Endocrinol 1974;3:69-96.

48 Morris JN, Everitt MG, Pollard R, Chave SPW Vigorous exercise in leisure time: protection against coronary heart disease. Lancet 1980;ii:1207-10.

49 Paffenbarger RS, Hyde RT. Exercise in the prevention of coronary hear disease. Prev Med 1984;13:3-22.

50 Leon AS. Physical activity levels and coronary heart disease (analysis of epidemiologic and supporting studies). In: Goldberg L, Elliot DL, eds. Medical Clinics of North America symposium on medical aspects of exercise. Philadelphia: Saunders, 1985:3-20.

51 Shephard RJ. Exercise in coronary heart disease. Sports Med 1986;3:26-49.

52 Kannel WB, Belanger A, D'Agostino R, Israel I. Physical activity and physical demand on the job and risk of cardiovascular disease and death: the Framingham study. Am Heart $\mathcal{f}$ 1986;11:820-5.

53 Pekkanen J, Marti B, Nissinen A, Tuomilehto J, Punsar S, Karvonen M Reduction of premature mortality by high physical activity: a 20-year follow up of middle-aged Finnish men. Lancet 1987; i:1473-7.

54 Mack TM, Pike MC, Henderson BE, et al. Estrogens and endometrial cancer in a retirement community. N Engl F Med 1976;294:1262-7.

55 Paganini-Hill A, Ross RK, Gerkins VR, Henderson BE, Arthur M, Mack TM. A case-control study of menopausal estrogen therapy and hip fractures. An Int $M$ d 1981; 95:28-31.

56 Ross RK, Paganini-Hill A, Gerkins VR, et al. A case-control study o menopausal estrogen therapy and breast cancer. FAMA 1980;243:1635-9.

(Accepled 27 May 1988)

haemagglutination test, received kidneys from donors positive for the antigen (table). They all received azathioprine and prednisolone as immunosuppressive agents.

Case 1-A 30 year old man received a kidney from his sister. Hyperimmune gammaglobulin was given in a dose of $3 \mathrm{ml}$ immediately before the operation and another dose three months later. Good graft function was achieved. Fifty months after transplantation cyclosporin was substituted for azathioprine because of a slow but steady decline in renal function. The patient remained negative for hepatitis $B$ surface antigen three years after transplantation. Antibodies to hepatitis B surface antigen were detected at two years but persisted for only six months. At the last review the patient's serum creatinine concentration was $276 \mu \mathrm{mol} / \mathrm{l}$, and his transaminase activities were normal.

Case 2-A 36 year old man received a kidney from his mother. Before operation and immediately afterwards he was given $4 \mathrm{ml}$ of hyperimmune gammaglobulin. Another dose was given three months later. Good graft function was achieved. The patient developed antibodies to hepatitis B surface antigen at
Correspondence to: DrChan
Patients, methods, and results

Four patients who were negative for hepatitis B surface antigen, as assessed by a reversed passive



\section{Department of Medicine,
University of Hong Kong, Queen Mary Hospital, Virus Unit, Queen Mary W K Cital, Hong Kong consultant medical microbiologist} positive for hepatitis B surface antigen to recipients negative for hepatitis B surface antigen. 